Mateja ŠMID HRIBAR

Jani KOZINA

David BOLE

Mimi URBANC

\title{
Public goods, common-pool resources, and the commons: The influence of historical legacy on modern perceptions in Slovenia as a transitional society
}

This article aims to study and clearly define the terms public good, common-pool resources, and the commons. Using path dependency analysis, interviews, and workshops among the general public and experts, we highlight the perception of public goods and the commons in Slovenia as a transitional society. The analysis reveals that the general public's understanding of these terms is still strongly influenced by communist socialist-era emphasis on social justice, equality, and access to goods for everyone, which can be at odds with the right to private property. Inadequate governance of goods that are considered public goods, but are in fact common-pool resources, can lead to conflicts and degradation of common-pool resources, which results in the loss of advantages providing wellbe- ing. Because people's lives depend on subtractable natural resources, it is necessary to raise awareness about them among the general public and professional community, emphasize their vulnerability, and explain that they cannot be accessible to anyone in unlimited quantities. Furthermore, in an international context, using the Slovenian case, we seek to improve the understanding of human behaviour and expectations concerning public goods and common-pool resources in post-communist transitional societies.

Keywords: public good, common good, common-pool resources, the commons, common property, space, governance, management, transitional society, Slovenia 


\section{Introduction}

The cultural landscape, either rural or urban, as a living space offers goods at various levels and for various groups of people. Owners are particularly interested in its economic aspect, whereas nonowners have their own expectations in terms of public and common goods (Šmid Hribar et al., 2015). Due to the recent past and the transitional state of Slovenian society, part of the general public in Slovenia believes that goods such as nuts, berries, and mushrooms, urban green areas, river banks, shores, and similar belong to everyone, and they are considered a public good. This is contrary to the belief of landowners (i.e., mostly farmers), who want to restrict the use of these goods. The misunderstanding arising from the perception of public goods pertains to urban areas as well. The distinction between the meanings of the terms public good and common good is not clearly drawn. The general public mostly uses the terms interchangeably. However, the term public good prevails and is used hereinafter in this article. The confusion is even greater regarding the goods typology, according to which in economic and environmental protection discourse the key characteristics of a good are its low/high excludability and low/high subtractability (Ostrom \& Ostrom, 1977; Ostrom, 2005). Rather than a public good, the goods mentioned above are, in fact, common-pool resources (CPRs) because they are difficult to exclude and have high subtractability of use.

Rather than checking the academic terms public good, common good, and CPR among the general public and experts, this article draws attention to the fact that the general understanding of a public good - irrespective of terminology - and the related rights is at times inappropriate and is the result of the past perception of entitlement to these goods. On the other hand, the pressures from owners to restrict access to these goods are growing stronger, generating a gap between private property rights and the privileges gained under the communist ${ }^{[1]}$ system. In fact, the privileges granted in the communist era have conferred advantages that current legislation preserves, and it thus restricts landowners in the use of certain goods. Article 67 of the Slovenian Constitution (Sln. Ustavni zakon ..., Ur. I. RS, no.75/2016) provides that the manner in which property is acquired and enjoyed shall be established by law to ensure its economic, social, and environmental function. Accordingly, we hypothesize that Slovenian society, which is a transitional society, considers many freely accessible goods in the cultural landscape - which are, in fact, CPRs - to be public goods that everyone is entitled to, whereby they come into conflict with private property rights. We assume that this is a legacy of Slovenia's recent past; that is, a result of political, ideological, economic, and social changes.
A lack of knowledge about CPRs and their mismanagement can lead to conflicts and resource degradation, resulting in the loss of the advantages promoting wellbeing. In transitional societies like Slovenia, there is a need for a clear definition of the terms public good and CPR. This will provide valuable help in understanding that some goods, even if they are openly accessible, are not a public good - they are subtractable and vulnerable, and constant open access to all cannot be taken for granted. Appropriate understanding of the distinction between public goods and CPRs is important because it affects the expectations and behaviour of the public toward the goods that play a key role in providing wellbeing. Such goods are CPRs mostly because owners do not restrict access to them, which is because access to these resources is a) difficult to restrict (e.g., forests, nuts, berries, and mushrooms) or b) they are traditionally not fenced off in Slovenia. The objectives are:

1. To explain the misunderstanding in the perception of public goods and CPRs in Slovenian transitional society, and to show how this is reflected in the conflicts related to access to CPRs;

2. To provide insight into what is considered a public good and a common good by the general public and experts in Slovenia; and

3. To draw attention to the clear distinction between public goods and CPRs to understand and raise awareness about the fact that openly accessible goods that are CPRs are not public goods and therefore cannot be accessible to everyone in unlimited quantities.

\section{Theoretical background}

In Slovenian legislation, the term public good is still not clearly defined; instead, it is used inconsistently and unsystematically (Vugrin, 2005; Šmid Hribar et al., 2015). When searching for a definition of public good, in economic and environmental protection discourse researchers in the second half of the twentieth century applied the criteria of its (non)excludability and (non)rivalry (Samuelson, 1954, cited in Ostrom, 2010; Musgrave, 1969, cited in Desmarais-Tremblay, 2014, which were later narrowed down and replaced by the criteria of low/ high excludability and low/high subtractability of use (Ostrom, 2010). By combining the criteria of (non)excludability and (non)rivalry, Musgrave and Musgrave (1973, cited in Desmarais-Tremblay, 2014) used a theoretical model to identify four types of goods, where along with private and public goods two other types were identified: goods whose consumption leads to no subtractions, but are not accessible to everyone (excludable), and goods that are subtractable, but where exclusion from consumption is difficult. The term common good was first used for the latter category. Despite being part of western political thought since ancient Greece (Lee, 2018) and a widely 
used concept as addressed by most political thinkers (Dupré, 1993), the concept of the common good is loose, imprecise, and prone to political manipulation (Jaede, 2017). According to Mansbridge (2013), the meaning of the concept is essentially contested. What makes the issue even more challenging is that the notions of common good, public good, and public interest are often used interchangeably (Mansbridge, 2013). Due to its low/high excludability and subtractability, this category of goods attracted researchers' attention. Vincent and Elinor Ostrom (1977; Ostrom, 2005) and their colleagues left a significant mark on this category by naming it common-pool resources, or CPRs. A CPR is defined as "a natural or manmade resource system that is sufficiently large as to make it costly (but not impossible) to exclude potential beneficiaries from obtaining benefits from its use" (Ostrom, 1990: 30). This characteristic does not depend on socio-political factors, but it is inalienable to CPRs, albeit not widely recognized. Due to their free accessibility, the term $C P R$ is often used interchangeably with public good.

The lack of knowledge of CPRs leads to mismanagement or misuse, which further leads to inappropriate legislation. This can lead to deterioration or even depletion of resources, as highlighted by Garrett Hardin in his famous essay "The Tragedy of the Commons". In this essay he underlined the fateful human trait according to which individuals act according to their own self-interest. Overfishing in the Adriatic Sea (Fromentin, 2009; Colloca et al., 2013) and managing denationalized forests in Slovakia (Kluvánková \& Gežík, 2016) are two recent examples. Excessive use of CPRs and inappropriate activities have tangible socioeconomic consequences (Rodela, 2012). Hardin's approach was successfully challenged by Elinor Ostrom (1990), who stated that the tragedy of the commons can be avoided by appropriate governance. Ostrom (1990, 2010 emphasized that neither the market (i.e., the neoliberal model) nor the state and private entities via concession contracts managed to provide desired solutions for sustainable governance of CPRs. Based on many international cases, she found that CPRs can also be governed by local communities (Ostrom, 1990, 2010. Ostrom won the Nobel Prize for her conclusion that, when facing a limited resource, people are able to act and collaborate for the common benefit (Ostrom, 2010; Anderies \& Janssen, 2013). In Slovenia these types of collaboration are known as agrarian communities, which governed and managed common lands for centuries (Vilfan, 1996; Petek \& Urbanc, 2007; Bogataj, 2012). During the communist era they were disbanded; however, they have been reinstated since Sloveniass independence. The notion of the commons adds confusion to the terms public good and common good. It relates to jointly owned goods that are governed by communities, which use collective actions with a specific set of rules, and they are frequently misinterpreted as a common good.
McKean (2000) pointed to this confusion and emphasized that common property should be classified as a form of shared private property. According to the author, it is necessary to distinguish between goods, rights, and entities/owners holding rights. These categories are either private or public.

In Slovenia, the confusion related to the terms public good and the commons is predominantly due to historical and institutional contexts. Such an effect is called path dependency, which is characterized by a sequence of historical events in a place, leading to the current institutional patterns or specific chains of events. By identifying historical events in an area and their interactions, one can determine the spatial, social, and other patterns therein (Godina, 2015). According to Heinmiller (2009), relatively little attention has been paid to path dependency in studying collective actions among resource users, although this can importantly affect governance. An analysis of common land property practices in the historical context of Portugal (Lopes et al., 2013) demonstrated that the current status of common land is closely connected with key historical periods. At the same time, it revealed the sequence of shaping the relations toward resources and rules that led to various land and legal forms of common land. According to Godina (2015), the significance of path dependency has been overlooked in planning and implementing social changes in post-communist societies, including Slovenia. As the main reason she identifies the ideologically influenced perspective on history, which is based on the idea of creating a discontinuity with communism. The same can be said for the communist or industrial society in relation to the agricultural society prior to 1945 . Additional confusion is caused by two key concepts from Slovenia's recent past: social ownership and workers' self-management. The Associated Labour Act (Sln. Zakon o združenem delu Ur.l. SFRJ, no. 53/1976), which introduced the concept of social ownership, does not provide a definition but rather the following comment by Grahek (1988: 14): "Workers thus appropriate part of income, but this is labour-based rather than ownership-based." Independent property management formed the basis for workers' self-management that was put into force in 1950 (Zakon o upravljanju ..., Ur. l. FLRJ, no. 43/1950). Both concepts, albeit with a different meaning, are still embedded in people's consciousness (Toplak, 2014) and affect the perception of goods. At least to a certain degree, these findings can be generalized to other post-communist countries of central and eastern Europe (Premrl et al., 2015, Markuszewska, 2018), where, due to socioeconomic changes as a consequence of regime changes and government decentralization, many gaps emerged between property legislation and rights in practice. The divide between de jure and de facto in managing various goods leads to the erosion of general interests to the benefit of individuals, causing deterioration and reduction of the stock of common-pool resources (Sikor, 2004). 


\section{Methods}

In Section 4, the path dependency concept is used as a methodological framework and, based on a review of the existing literature, we identify three historical periods affecting the perception of the terms public good and the commons in Slovenian transitional society. Using this approach, we draw attention to the role of the (in)appropriate understanding of natural resources' characteristics and show that they can be governed sustainably. Section 5 lists cases of public and common goods in pilot areas and emphasizes the advantages and conflicts resulting from these goods. We were interested in what locals in pilot areas and experts consider a public good and what they consider a common good. In the autumn of 2015 we carried out a workshop with locals in each of the three pilot areas (the local communities of Bevke, Čadrg, and Kosovelje) on benefits of the landscape and public and common goods in their settlements. Between March and November 2016, we carried out thirty-one in-depth structured interviews with locals and twenty-three interviews with public sector stakeholders whose work indirectly or directly deals with landscapes (in terms of rural development, protected areas, natural and cultural heritage, agriculture, forestry, and hunting). The interviews lasted fifty-three minutes on average and consisted of three sets of questions concerning an individual's perspective on the cultural landscape, in which the third set contained questions on public and common goods in the landscape, their benefits, and potential conflict situations.

\section{The impact of path dependency on understanding public goods, common-pool resources, and the commons in Slovenia}

In Slovenia one can distinguish between three important historical periods connected with broader political, economic, and demographic changes. Basing his work on the sector theory (Small \& Witherick, 1986), Klemenčič $(1989,1997)$ writes about various development stages: demographic, socioeconomic, geographic, and other stages that left their mark on the landscape and people. Of special interest are the socioeconomic stages that, through changing the shares in employment sectors, suggest a transition from an agricultural and industrial society to a post-industrial (information) society. Until the 1960s, Slovenian society was mostly agricultural, which was followed by a rapid but brief period of industrialization until the 1990s, which was then followed by tertiarization of society. The communist government after the Second World War and the transition to the market economy after independence in 1991 played a decisive role. Accordingly, we decided to demonstrate the evolution of the perception of public goods and the commons across three historical milestones: the agricultural period until the end of the Second World War (1945); communism, collectivism, and industrialization (1945-1991); and independent Slovenia after 1991, characterized by tertiarization of the economy, individualization of society, and transition to a market economy.

\subsection{Agricultural society (until 1945)}

Slovenia's agricultural society was economically based on the primary sector (agriculture, hunting, fishing, and forestry). Fragmented private property prevailed, and to a limited extent pastures and forests were owned by village communities, where the use of these goods was shared (Vilfan, 1996). Because communities depended on their resources, they were generally careful not to deplete or damage them (Rodela, 2012). Slovenia has a rich tradition of common lands that had great economic significance in terms of livelihood, not only for individual families but for entire villages (Petek \& Urbanc, 2007). Common lands date back to the period of tribal communities, and in some places they have been preserved since feudalism (Vilfan, 1996). The General Civil Code (German: Allgemeines bürgerliches Gesetzbuch) of the Habsburg Monarchy, which entered into force on 1 January 1812, distinguished between a) public goods, which covered things available to all citizens (e.g., public roads and watering places), b) municipal goods, from which residents benefited, and c) municipal property, from which municipal costs were covered (Vilfan, 1996). However, Vilfan points out that the various types of common property are difficult to classify according to these legal categories and that the right to common or municipal goods differed from one place to another. There are several regional and diachronic versions of the umbrella terms; common lands were called komunšna, komunela, and gmajna (Vilfan, 1996: 237) and agrarian communities were called soseska (Petek \& Urbanc, 2007), sose(d) ska, srenja, jus, and skupnina (Bogataj, 2012). Along with governing common lands, the agrarian community was in charge of managing and maintaining roads and watering places, for example (Ravnik, 1998). By the end of feudalism, the rights to common lands were more or less uniform and depended on a person's affiliation with a local community, but afterwards these rights started to differentiate. Vilfan (1996) emphasizes that the remains of the former village communities were preserved in the cases of collective governance of common lands. The economic aspect prevailed in their governance, which was environmentally sustainable due to the low level of technological development. Nevertheless, there were practices that led to depletion or even loss of natural resources. Such a case is peat in the Ljubljana Marsh. In the early nineteenth century, right before intensive drainage, there were 1,500 hectares of peatland in the marsh (Pavšič, 2008). The Franciscan Cadas- 


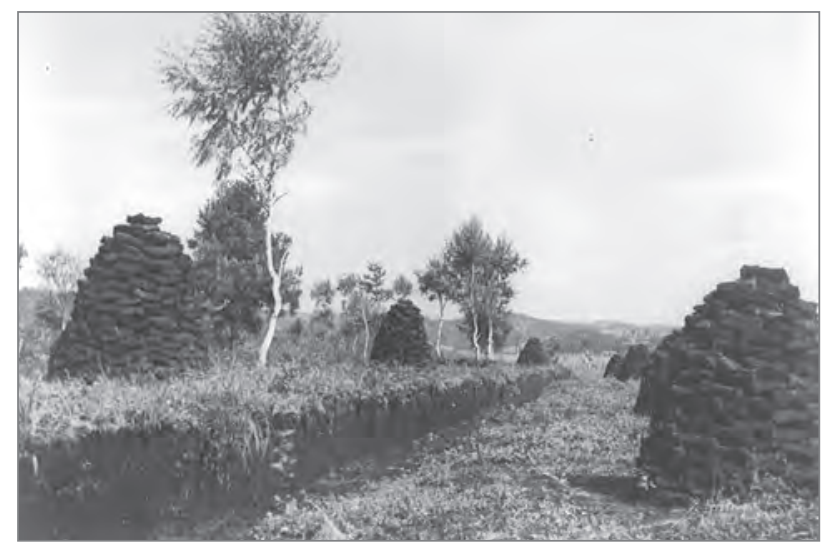

Figure 1: Peat cutting and drying in the Ljubljana Marsh (source: archives of the Ljubljana Marsh Protected Landscape Area).

tre shows that between 1824 and 1827 many wet meadows and pastures were common land (Šmid Hribar, 2016). Due to drainage and division of the land after 1830, the former common pastures became privately owned. In the second half of the nineteenth century, the peatland was intensively exploited by landowners for economic gain. Despite estimates that the peat reserves would suffice for another 229 years, the peat was depleted in a few decades and consequently the elevation of the marsh decreased (Melik, 1927). The flood risk in the Ljubljana Marsh increased, the functions of the landscape and ecosystem services changed, and the consequences are felt by all current residents (Šmid Hribar, 2016).

\subsection{Industrial society (1945-1991)}

The communist period, which was accompanied by significant structural and ideological reforms of the social, political, and economic system, had a significant impact on today's perception and governance of public goods and the commons. Nationalization and the resulting expropriation of major landowners are particularly important. The introduction of a land maximum allowed them to keep a maximum of thirty-five hectares (Zakon o agrarni ...., Ur. l. LRS, no. 10/1948), and from 1953 onwards only a maximum of ten hectares of arable land (Zakon o kmetijskem ..., Ur. l. FLRJ, no. 22/1953). Along with farmers, expropriation also pertained to agrarian communities (Zakon o agrarnih skupnostih, Ur. 1. LRS, no. 52/1947; Zakon o razpolaganju . .., Ur. 1. SRS, no. 7/1965), which interrupted the continuity in managing subtractable natural resources. Based on the case of the selected agrarian community of Škrbina, Rubije, and Šibelji, Czerny (2014) assumes that the lack of continuous collective governance of agrarian communities affected the perception of their members. He emphasizes the distinction between the governance objectives of both passive and active members of an agrarian community. Active members prefer economic goals, whereas passive members prefer environmental goals. Both categories of members consider communication an important part of the agrarian community's decision-making. They also recognize the importance of coordination regarding the use of common-pool resources, which, in their opinion, is essential to the agrarian community's survival in the long run (Czerny, 2014). The agricultural reform that caused the expropriation of major landowners also influenced the collectivization and establishment of major national systems, such as communist cooperatives, agricultural combines, and national forest companies (Jepsen et al., 2015; Premrl et al., 2015). There emerged a major gap between agricultural combines averaging two hundred hectares and agricultural holdings averaging 5.2 hectares (Drozg, 2007).

Similar to other eastern European countries, after the Second World War Slovenia saw the implementation of a centrally planned economy (Jepsen et al., 2015). Private ownership was replaced by state (national) and social ownership (Urbanc, 2002). The power of decision-making was transferred from individuals, agricultural holdings, and local communities to the state level (Partlič, 1989) and, through the introduction of social ownership and workers' self-management, to employees (Šetinc, 1979; Toplak, 2014). By introducing new forms of ownership, the centuries-old existing and emerging connections between subtractable resources and their local communities - that were, in fact, their managers - started to break down. As a consequence, knowledge about the resources' characteristics was gradually lost. To a great extent, the responsibility for their governance was transferred to state institutions that, because of their physical and/or cognitive distance, were not susceptible to sustainable management. According to Partlič (1989), Pučnik was one of the first critics of the postwar agricultural policy. As early as 1963, in his ideologically contested article "O dilemah našega kmetijstva" (Dilemmas in Our Agriculture), Pučnik questioned the goals of the agricultural policy, asking whether its aim was to regulate the food supply or to abolish private ownership and introduce collective cultivation (Pučnik, 1963, cited in Partlič 1989: 433). The negative attitude toward the farmer as a private producer (Urbanc, 2002; Razpotnik Visković \& Seručnik, 2013) and the systematic establishment of industrial companies across Slovenia affected the extensive social layering from agricultural to non-agricultural activities and the related urbanization or demographic and spatial urban growth (Drozg, 2007). The fragmentation of land, also as a consequence of the agricultural reform, caused the formation of an extensive stratum of parttime farmers. Because of their weak economic power, they preserved small plots of land, diversity of agricultural landscapes, and extensive land cultivation (Urbanc, 2002), and they had an inhibitory effect in terms of intensive deagrarization. Thus, they played an important role in maintaining the traditional cultural landscape (Razpotnik Visković \& Seručnik, 2013). 


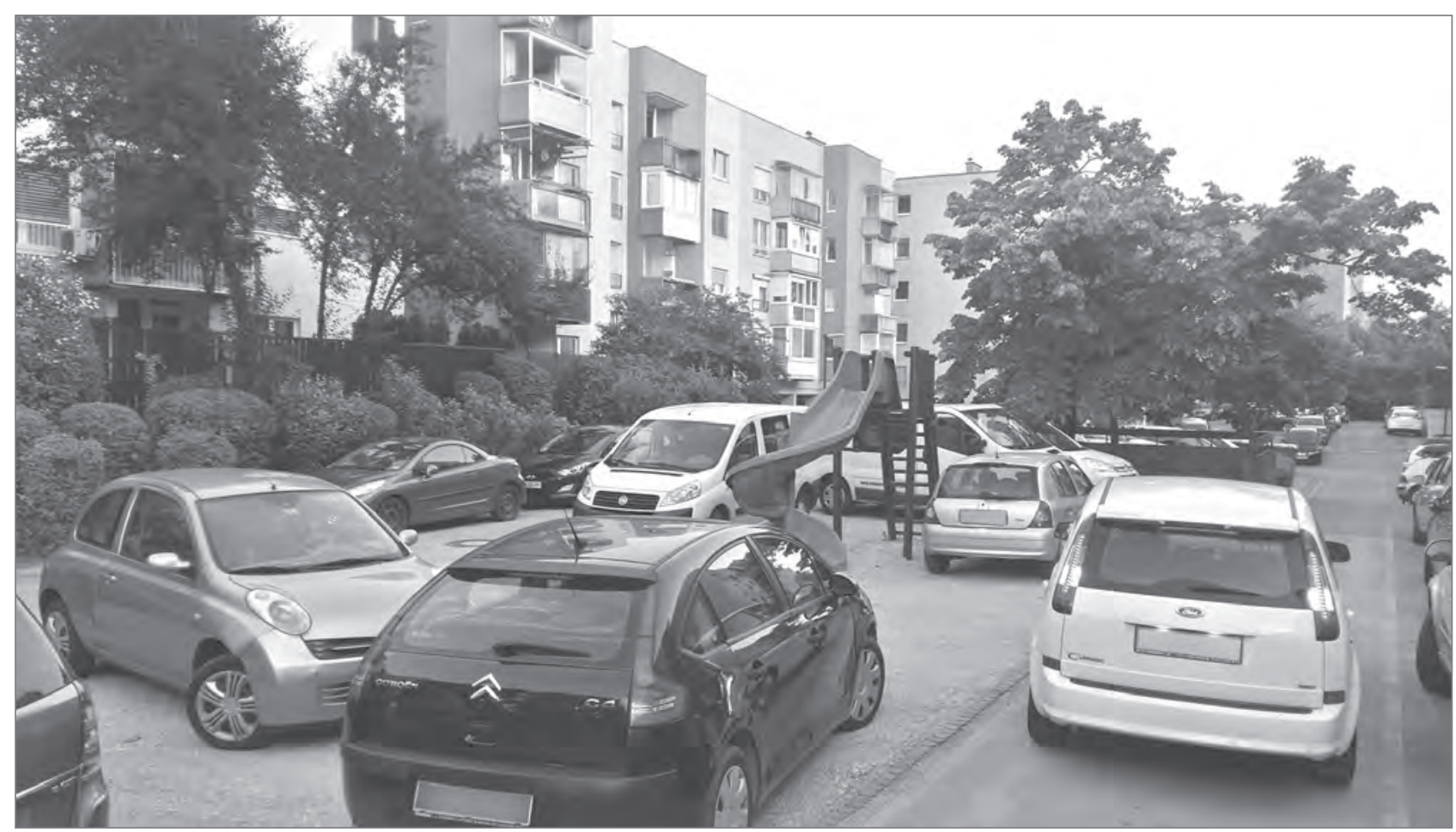

Figure 2: The residential green urban areas that started to emerge under communism are important urban commons, but they are also a CPR, and so they need to be governed (photo: Peter Stavanja).

With industrialization of society and deagrarization, urban space came to the forefront (Drozg, 2007), and the problem of governing the commons was also transferred into this space. The result of poorly thought-out structural and ideological reform is still evident in public green areas next to apartment buildings (Zlatkova, 2015; Simoneti, 2016), which ought to allow for a better quality of life and connect people with nature. Nevertheless, public green areas have become increasingly at risk in recent decades.

\subsection{Post-industrial society (since 1991)}

Slovenia became a post-industrial society in 1991, when the share of those employed in the service sector exceeded the share of industrial workers (Klemenčič, 1989, 1997). There were many consequences of the political, social, and economic changes that followed independence and the transition from a totalitarian communist social system to democracy and market capitalism (Drozg, 2007). This was paired with a value shift in society, associated with the reduced significance of collectivism and increasing individualization.

In terms of public goods and the commons, two types of processes are particularly significant. The former relates to the elimination of social ownership as the prevailing form of ownership relationships from the communist era, and the latter relates to the revival of methods of collective govern- ance of subtractable natural resources, which was present in the agricultural period. The removal of social ownership was accompanied by denationalization and privatization, but there is an important distinction between the two. With the former, ownership was relatively clear and understandable: the properties were returned to the injured parties or their heirs (Premrl et al., 2015) and the condition before nationalization was re-established. With privatization, ownership is a much looser category, and social ownership and control of means of production were replaced by dispersed and non-transparent private property. Inappropriate reallocation of wealth and power among the members of the political and economic elite could result in uncontrolled privatization (Lorenčič, 2009) and mismanagement of state-owned assets. This is characteristic of new European Union member states (Tomšič \& Vehovar, 2012). With the onset of the economic crisis, the focus of privatization shifted from state-owned companies to space (land), energy, and water, which can have characteristics of CPRs and are essential for survival. Denationalization revived methods for governing common land that existed prior to industrial society. The legislation adopted after Slovenia's independence allows for the reestablishment of agrarian communities and the restitution of properties and rights (Petek \& Urbanc, 2007). However, due to the poorly conceived Denationalization Act of 1991 (Sln. Zakon o denacionalizaciji, Ur.l. RS, no. 27/1991), which allowed the restitution of land to heirs, agrarian communities face many problems in conducting ju- 
dicial proceedings because this act has led to privatization of former common land, which will probably result in changed land use (Šmid Hribar et al., 2015). According to Cerar et al. (2011), the nationalization procedure under communism abolished or expropriated between one thousand and 1,500 agrarian communities, but the size of their land is not known. Premrl (2013) reports that 638 agrarian communities are registered in the administrative unit registers, of which 547 are potentially active; the procedures regarding property restitution have not been completed for forty-eight agrarian communities. A total of 77,486.47 hectares of land was returned to agrarian communities, which is $3.67 \%$ of Slovenia's territory (Premrl, 2013). Compared to the agricultural period, when the significance of common land was mostly economic, today the focus is on preserving and maintaining ecological balance, biodiversity, the open agricultural cultural landscape, and rural areas in general (Petek \& Urbanc, 2007; Jepsen et al., 2015; Šmid Hribar et al., 2015).

The ongoing privatization process, transformation of utility services, and public services for public green areas can be linked to the poor maintenance of older high-rise neighbourhoods that are at risk of degradation if no comprehensive renovation is put in place. Without specific guidelines, criteria, and conditions for division of land among public and private entities, municipalities acted differently in relation to maintaining green areas. This is reflected in poor maintenance, appropriation, reorganization, and speculative purchases. Currently, the deterioration of quality in older neighbourhoods of Slovenian towns is not critical, but poor maintenance may lead to reducing the options for new developments, which may ultimately result in irretrievable loss of green areas (Simoneti, 2016). In Slovenia, a pressing concern is recreation in forests, including the widespread gathering of nuts, berries, and mushrooms. The dissatisfaction of forest owners is even greater when the gatherers and recreational users are not local. In the autumn of 2016, "chestnut wars" occurred in some places, when angry locals stood up to visitors because of their excessive gathering of chestnutss, negligent parking, and driving off-road (Omladič, 2016).

\section{Public and common goods in Slovenia}

\subsection{Perception of public and common goods among locals}

Most locals at the three case study sites are unable to clearly distinguish between the terms public good and common good. An interviewee from the village of Bevke stated: "I don't distinguish between the two well enough, I find them very similar." Sometimes one thing is understood as a public good and common good at the same time. Thorough interviews suggested that locals mostly define common goods and public goods in relation to ownership rights; that is, the rights to use a good. The majority feel that a public good is a good that is publicly owned, free of charge, and can be used by all residents. Accordingly, public goods are understood as public areas owned by everyone; for example, municipality-owned land, municipal properties, roads and paths, troughs and watering places for livestock, wells, ponds, infrastructure, waste bin areas, land owned by the Slovenian Farmland and Forest Fund, cemeteries, monuments, and viewpoints. Locals perceive water as a public good rather than a common good. They also consider services intended for everyone to be a public good (e.g., public health services, fire services, hospitals, and schools).

On the other hand, under common goods locals understand everything that the residents of a settlement use: natural resources, common lands, indoor or outdoor areas, infrastructure, and things that they made, built, or established in village community campaigns and for their use. According to one interviewee from Kosovlje: "A common good is everything that we do together." Shared air, water, peace, and access to heritage were given as the main examples of common goods. The key is shared ownership, common work, benefits, and use. Locals in Čadrg feel that a common good in their settlement is drinking water, the village water supply system, common land for grazing, ecological farming, cutting wood on common land, a viewpoint with a bench, an area for planting walnuts, a cheese factory, and troughs for watering livestock. In Kosovlje, common goods are shared wells for watering gardens, roads, footpaths, a pond, a bonfire area, a waste bin area, parking space, a private garden that the owners open and share with others, high-speed internet access via optic cable, new flags, mushrooms, and herbs. In Bevke, common goods are considered certain areas under nature protection, drinking water and a water reservoir, medicinal plants, and socializing in areas that were acquired together, such as a fire station, sports park, kindergarden, school, church, or cemetery. In the locals' opinion, all of these goods, similar to public goods, improve their quality of life and offer benefits.

In all three pilot sites, conflicts have arisen in relation to the use of public and common goods. In most cases, these were due to the mismanagement of water resources. In one case, the views differed about establishing control of drinking water quality and the related financial and management costs. The residents reached an agreement and adopted an appropriate solution. Another case was a deep pond with drinking water, which was almost destroyed by inappropriate construction work and where the water is no longer fit for drinking; there are attempts to restore the pond. The last case is connected with a water resource that the neighbouring municipality depends on. The 
residents would permit the pumping of drinking water on the condition that the road running through the neighbouring municipality be improved. There is also the issue of forests that once belonged to the agrarian community, where there are hunting grounds owned by the state. The residents are against any tax burdens on land that they are not allowed to manage.

\subsection{Perception of public and common goods among experts}

Experts also had difficulty distinguishing between public and common goods. Nevertheless, in their work they mostly use the term public good and understand it as that which is necessary for survival, so that everyone must have access to it. These are roads, thoroughfares, forest roads, and paths - in short, infrastructure that allows for passability and good access to land, forests, and the coast. Others mentioned peace, views, a preserved landscape, space, forest and agricultural land, nature, preserved plant and animal species, water and water supply, schools, markets, trees, and parks. To a great extent, experts also connect public goods with ownership and frequently believe that, due to encroachment into private property, they are often a burden for owners. A spatial planning expert felt that complications also occur when the municipality is the owner of some public goods and the state is the owner of others, which shows the need for multilevel governance.

Reflections on common goods were rare and referred to things that are in shared use: roads, common pastures, meadows, forests, water, and the landscape - that is, similar to what was mentioned in relation to public goods. With regard to common goods, individuals emphasized that use can conflict with private interests, and a representative of cultural heritage protection services mentioned that "people become aware of a common good only when they start losing it." Another concept associated with common goods was agrarian communities managing common lands and goods (e.g., firewood) that the members of individual agrarian communities can use. Among the benefits of common goods, they specifically mentioned mushrooms, wild asparagus, recreation opportunities, and aesthetic values in an area.

Experts were also aware of the conflicts originating from excessive or large-scale use of such goods. They mentioned the conflict in using the area at the confluence of the Tolminka and Soča rivers, which is practically closed off in the festival season, during the entire summer. This angers the local population, which cannot swim or walk there without a ticket. In this area there is also a forest with special significance, but because of the large number of festival visitors it has been subject to degradation. Conflicts of interest are also identified on the banks of rivers, which are freely accessible in Slovenia. During the summer, visitors come from various parts of Slovenia and leave behind waste, which angers the residents even further. The problem of exploiting the Soča River has been stressed, with conflict between fishermen, kayakers, and rafters. A solution was found in the spatial and temporal zoning of various activities. A similar management mechanism will be probably necessary in relation to using the skydiving airfields because the increased number of skydivers and the time that they spend there disturbs the wildlife. Mushroom picking is also becoming a problem.

\section{Discussion}

The first objective of this article was to explain the conflicts in perceiving certain goods that the Slovenian general public considers public goods, which land owners disagree with. Path dependence analysis was used to clarify this ambiguity. It became evident that the perception of these goods is still strongly influenced by ownership and the terms social ownership and worker's self-management from the times of communist Yugoslavia, and to a smaller degree also by the events in the agricultural period. As expected, in the agricultural period, at least in areas with settlements that go back hundreds of years, people took into account the vulnerability of natural resources because their sustainable use was of key importance for the community's survival. When governing subtractable natural resources, the locals organized themselves into agrarian communities and, by following strict rules for using the commons, they avoided the tragedy predicted by Hardin (1968). They showed that subtractable resources can be governed so that the resource is preserved for future generations despite consumption of certain goods, which was later proven by Ostrom on various international cases $(1990,2005)$. Despite good practice examples, there were cases of overuse even back then, which were mostly due to poor knowledge of the resource in question and land division. A case in point is the destruction of peat in the Ljubljana Marsh in the second half of the nineteenth century, when the new owners were mostly motivated by economic gain. Subtractable natural resources (e.g., drinking water, ponds, forests, and pastures) have remained important for the quality of life to this day. At the Čadrg pilot site, the former practice of collective governance of subtractable resources was passed on to modern times. The locals successfully manage common forests, pastures, and water, but are hampered by the lack of understanding of the state, which, on the one hand, encourages them to register common forest lands in the land register, but it does not grant them the right to shared decision-making in wildlife management. 
In the industrial era of Slovenia, which was then part of Yugoslavia, an ownership conflict occurred between farmers on the one hand and the state on the other, due to implementing the concept of social ownership. This concept must not be equated with the concept of the commons from the agricultural period because the concept of social ownership was based on labour whereas the concept of the commons was based on collective governance of jointly owned subtractable resources. According to Caffentzis (2010), the ideology of communism created the imaginary impression of sharing and co-management of social wealth by the citizens, whereas the reality was that most of this was based on restricted management by either bureaucratic or capitalist criteria. Similarly, Pučnik (1963) connected the abolition of private ownership in rural areas with social injustice and economic discrimination against the agricultural population. The abolition of agrarian communities and nationalization of common land after the Second World War was confirmed by Obeng-Odoom (2016), who finds that their existence is undermined by external, rather than internal, threats. In Slovenia these communities were not abolished under capitalism or imperialism, but, ironically, under communism. The transfer of ownership and/or governance onto public institutions has often proven to be problematic (e.g., Zlatkova, 2015; Simoneti, 2016). On the one hand, resources became publicly owned, but because people were not aware of their vulnerability they were often poorly managed, which resulted in deterioration. In rural areas this was reflected in the overgrowth of agricultural land due to ideological support for industrialization, and in towns and cities it was reflected in the degradation of common green areas near apartment buildings. The responsibility for the consequences of poor governance, or even a lack thereof, mostly lies with "remote" public institutions, which, due to their lack of knowledge and weak personal ties, often failed to see that such natural resources had characteristics of CPRs. The interviews with locals point to this ongoing conflict because they are mostly critical of the state's governance of subtractable natural resources (e.g., forests and water) and feel that the state is not a good manager in this respect.

As "resistance" to communist collectivism, post-communist countries eagerly adopted neoliberalism (Smith \& Timár, 2010), in which the state has significantly less chance of directing local and regional development than in a planned economy (Drozg, 2005). The pressures of forest owners to limit the exploitation of nuts, berries, and mushrooms to owners only are well known (Kumer, 2017). Section 5.2 provided the example of closing the area at the confluence of the Soča and the Tolminka rivers during the summer festival, which is incomprehensible to the Slovenian public and is, in fact, usurpation of a common space that the locals use for walks and relaxation. The concessionaire officially paid for the right to close the area, but the municipality should also consider locals' right to the area and adjust its governance accordingly. The path dependency analysis in three periods revealed that the consequences of changing the impact and power of individuals, the community, and institutions concerning subtractable resource governance in Slovenia are still evident in the different perception of public goods and the commons and, as a result, in the various expectations of the public and owners regarding these goods.

Interviews with locals and experts offered insight into their perception of public and common goods, which was the second objective of this article. It turned out that they almost did not know the difference between the terms and perceived them as something that is freely accessible. The distinction is mostly related to property rights and economic benefit, bringing the meaning of common good closer to the commons. We assume that this is a consequence of the spatial and temporal contexts and processes that shaped, and continue to shape, the perception of the commons and its ownership (agrarian communities, nationalization, denationalization, etc.). Locals often equate common goods with common things, and they use the expressions synonymously. The commons is characterized by common property, where - depending on its (non)accessibility - a good can be a private good or a CPR, but not a public good. A forest owned by the agrarian community or green areas next to apartment buildings are CPRs, but this is not the case with a fenced-in common pasture or a shared cheese factory with limited access. In all three pilot areas, the locals dedicate significant effort to the existence and improvement of the commons; they volunteer in joint campaigns and are well aware that in improving the quality of life they mostly depend on themselves and their input, including financial. In recent decades they have used their own resources to independently build water supply systems, telephone and electric installations, and even roads. They invest in restoration and establishment of cycling and walking routes, clean the surroundings, restore dry stone walls, and maintain and build common spaces. There are some things that the locals are willing to share with each other, but they become upset when someone wants to benefit from their shared work and input. This suggests that the role of the commons in improving the locals' quality of life is important. A positive attitude toward working together to shape and restore the environment that the community manages is clearly a characteristic of Slovenian rural areas. In Slovenia, the commons is understood beyond common ownership because it relates to common village matters, which makes the community even stronger and builds local identity.

Among the experts, we perceived the connection of common goods with common use and institutions that manage common land (e.g., agrarian communities). They are well aware of the conflicts arising from the increased or undefined use 
of certain goods (e.g., space, drinking water, and mushrooms) and they find that solving these conflicts of interest requires dialogue among everyone involved, which should be followed by multilevel governance. According to Rodela (2012), key decisions regarding CPRs in Slovenia are still made by public institutions (institutes, ministries, and agencies), and their sectoral policies and development programmes are implemented by relevant branch offices. This manner of CPR governance is a legacy of communism, in which the centralized state apparatus gained in power and importance. An alternative to this kind of governance is contemporary foreign models of complex CPR governance, based on various concepts such as co-governance (Somerville \& Haines, 2008), multi-actor governance (Schut et al., 2014), and multilevel governance (Hooghe \& Marks, 2003). The essence of these concepts is a mutual formation and representation of various communities to introduce more efficient policies concerning CPR governance.

The third objective of this article was to draw attention to the clear distinction between public goods and CPRs to understand that freely available goods that are CPRs are not public goods and therefore cannot be accessible to everyone in unlimited quantities. By stressing social and spatial justice, equality, and access to goods for everyone (Drozg, 2005), the communist era strengthened the public opinion that access to and the benefit of these resources (e.g., nuts, berries, and mushrooms, and access to the coast) is the public's inalienable right. The problem is that the public still perceives these goods as public goods and is not aware of the negative consequences of excessive or inappropriate use. This confirms Heinmiller's conclusion (2009) that past patterns can lead to deep-rooted perceptions, which are often connected with old rights. In the agricultural period in Slovenia, collective governance of subtractable resources was already in place. However, in the communist era, this type of governance was prohibited and replaced by a system that treated everything as social property, without being aware of the subtractability of natural resources. In the present day we feel the consequences of both practices, which conflict with one another and influence the current perception and expectations of the general public, the professional community, decision-makers, and landowners. However, despite the many weaknesses of the former communist system, the authors of this article have identified goods such as free access to riverbanks, lakes, and forests, walking in forests, footpaths outside forests, gathering nuts, berries, and mushrooms in permitted quantities, and so on as an important privilege of the previous system and an advantage that greatly improves wellbeing while not causing any damage to the owners. Similar privileges to land were pointed out by George at the end of 19th century (cited in Obeng-Odoom, 2016), whereas Ostrom and her colleagues generally did not address them. To maintain these privileges, it is crucial to raise awareness among the public that all of these goods are not a public good - that is, something that everyone has access to in unlimited quantities - but rather that these goods have characteristics of CPRs due to their free access and subtractability.

At the same time, we must raise awareness among owners about how ownership per se does not grant an unconditional right to the use of natural resources. Slovenia's general public is justified in fearing appetites for privatization, concessions, or licencing, which greatly threaten Slovenia's subtractable natural resources due to economic interests. Very telling resistance to such trends is the inclusion of the right to drinking water in the Slovenian Constitution (Sln. Ustavni zakon ..., Ur. 1. RS, no. 75/2016), although it should be stressed that the constitutional legislator still does not understand that, rather than a public good, water is a subtractable natural resource. This characteristic, which the Slovenian public perceives intuitively, was what drove the efforts to include the right to water in the constitution. The inclusion itself does not protect water resources - they remain vulnerable and subtractable. In May and July 2017, the Slovenian public was shaken by two ecological disasters that, along with soil and air, affected water resources. It was shown that the mere amendment of the legislative framework with associated regulations is not enough. Concrete adjustments, clear rules, control, and, ultimately, sanctions for improper water resource governance and management are necessary. A particular problem in Slovenia is the conversion of fertile land into industrial zones. Each such investment requires careful deliberation because fertile land is a natural resource and its degradation is irreversible. Due to the growing number of users and conflicts of interest, green areas near apartment buildings are particularly affected.

This article draws attention to the fact that if people fail to take into account the subtractability of a good they are at risk of depleting the good or resource. Sometimes, particularly from the aspect of the ecosystem, depletion can be caused by the division of the resource into smaller units. In order to avoid this, past generations developed collective governance systems with specific sets of rights and rules. They shared the yield (e.g., firewood), but not also the CPR stock (i.e., the forest in this case). This confirms the finding by McKean (2000), who states that the right to goods was privatized without dividing it into smaller parts. Social ownership in communism was based on this concept; the difference was that the right was not transferrable and ceased with termination of employment. A recent example of CPR governance in urban areas is green areas around apartment blocks. The residents become organized, and they grow bushes and trees without dividing the green areas because the individual parts of land would be too small to grow trees. Through rules, conditions, and sanctions, they 
Table 1: Glossary

\begin{tabular}{llll}
\hline Slovenian term & English term & Brief explanation & Example \\
\hline Javno dobro & Public good & $\begin{array}{l}\text { A good that is neither excludable nor } \\
\text { subtractable }\end{array}$ & UV radiation, peace, roads, safety, etc. \\
\hline Skupni vir(i) & $\begin{array}{l}\text { Common-pool } \\
\text { resources (CPRs) }\end{array}$ & $\begin{array}{l}\text { A good that is not excludable but is } \\
\text { subtractable }\end{array}$ & $\begin{array}{l}\text { Nuts, berries, and mushrooms, drinking wa- } \\
\text { ter, access to the coast, freely accessible gre- } \\
\text { en areas in high-rise neighbourhoods, etc. }\end{array}$ \\
\hline Skupno & The commons & $\begin{array}{l}\text { A special form of jointly shared private property, } \\
\text { managed by the community according to a } \\
\text { specific set of rules; commons can be CPRs } \\
\text { (e.g., nuts, berries, and mushrooms), but not } \\
\text { necessarily, or a private good (e.g., a cheese factory) }\end{array}$ & $\begin{array}{l}\text { A village walnut grove, common land, local } \\
\text { community premises, community gardens, } \\
\text { etc. }\end{array}$ \\
& & &
\end{tabular}

become involved in the governance and management of their green areas, which are CPRs rather than a public good. The lack of organization among residents can lead to degradation of green areas in their immediate surroundings. A group of people may even take it one step further; they may rent or purchase a piece of land and, for example, plant walnut trees there, as was the case in Čadrg, or fruit trees and vegetables in urban neighbourhoods. The produce grown on such land is not a public good. This is typical common property or the commons, but, although it is known who can benefit from it, in the case of free access and given their subtractability these goods have CPR characteristics. This is also the case with the produce from the urban orchard planted in Ljubljana’s Vič neighbourhood, which has been vandalized several times due to poor governance. Even though it is located in a public area, it is not public good, but a CPR due to the good's subtractability and free accessibility. Similarly, blueberries, mushrooms, and chestnuts in the forest are CRPs rather than a public good. Table 1 provides a short explanation of the key terms and examples to avoid any further ambiguity concerning public goods, CPRs, and the commons, and to promote appropriate governance.

Finally, let us emphasize the role of ownership. As discussed in the theoretical background section, the key characteristics of goods lie in their low/high excludability and low/high subtractability, rather than ownership. However, the role of ownership becomes particularly evident in governance, when the owner can restrict access to the source or good. Because of economic profit for individuals or a minority, the privatization of a natural resource can lead to its depletion although the local community depends on it. It becomes of great importance who decides about the access to a resource and about how it is governed. Past generations were aware of how important it was for local communities to own the subtractable natural resources in their immediate surroundings. The residents of Čadrg are well aware of this because their efforts helped them preserve the right to govern their water resources. Duraippah et al. (2014) mention that lately in Japan the concept of the "new commons" has been put in place, when a group of individuals starts to manage abandoned overgrown areas.

\section{Conclusions}

The path dependency analysis revealed that the past socioeconomic systems undoubtedly influenced the present perception of public goods and the commons, which must be considered in future governance. Through common lands, the rich legacy of agrarian communities in Slovenia left behind a diverse governing system of subtractable natural resources. The communist legacy is reflected in stressing the right of access to goods for all residents, who perceive many goods as public goods. This belief can result in unjustified expectations. The additional influence of the former system is still found in the rigid and centralized state governance. The post-communist era resulted in denationalization, the revival of collective governance of subtractable resources, and also uncontrolled privatization of various goods, motivated by the desire for economic gain for individuals and minorities. In Slovenia this caused the general public's fear of water privatization, which drove efforts to include the right to water in the constitution. On the other hand, excessive gathering of nuts, berries, and mushrooms, and inconsiderate use of forests anger landowners and lead to chestnut and mushroom "wars", which are a consequence of the aforementioned historical factors.

By studying the perception of public and common goods among locals and experts, we found that the interviewees consider ownership to be the main difference between the two concepts, in which stakeholders make decisions in terms of their own participation or direct benefit. A common good is perceived by locals and experts as something that is owned, governed or managed by the local community, which brings the term closer to the term the commons. As soon as ownership is transferred to a public institution (e.g., a municipality or a ministry), it generally becomes perceived as public good. 
In order to avoid conflicts, natural resource degradation, and potential loss of the privileges that improve wellbeing, we seek to raise awareness among the Slovenian general public and professional community about the distinction between public goods and CPRs. Understanding the distinction between these two concepts should be included in the educational system and other forms of expression. A detailed review reveals that not many goods fall within the category of public goods. Many natural resources were not at risk for centuries because people did not know how to use them or their use was negligible. Until awareness is raised among the general public and the professional community that, along with free access, the key characteristic of CPRs is the subtractability of their use, their governance will be inappropriate and can lead to unfavourable use, which will mostly affect the local communities that depend on the resource. The public must understand that many goods that are currently perceived as a public good are, in fact, CPRs, which are freely accessible, but nevertheless subtractable. The public must assume a conscientious attitude towards the use of these resources, which can by no means be taken for granted. Only proper governance with clearly specified rights of use can preserve and maintain CPRs, and so it is essential that the public understand the essence of public good and CPRs, as well as the role of collective governance in sustainable resource management. This understanding should be transferred from rural to urban areas and also be taken into account in governing urban spaces, such as green areas next to apartment buildings, public orchards, community gardens, and so on. Furthermore, in an international context, using the Slovenian case, we seek to improve the understanding of human behaviour and expectations concerning public goods and CPRs in post-communist societies in transition. Socioeconomic and political contexts with corresponding ideologies play a crucial role in this.

\section{Mateja Šmid Hribar}

Anton Melik Geographical Institute, Research Centre of the Slovenian Academy of Sciences and Arts, Ljubljana, Slovenia

E-mail: mateja.smid@zrc-sazu.si

\section{Jani Kozina}

Anton Melik Geographical Institute, Research Centre of the Slovenian Academy of Sciences and Arts, Ljubljana, Slovenia

E-mail: jani.kozina@zrc-sazu.si

\section{David Bole}

Anton Melik Geographical Institute, Research Centre of the Slovenian Academy of Sciences and Arts, Ljubljana, Slovenia

E-mail: david.bole@zrc-sazu.si

\section{Mimi Urbanc}

Anton Melik Geographical Institute, Research Centre of the Slovenian Academy of Sciences and Arts, Ljubljana, Slovenia

E-mail:mimi.urbanc@zrc-sazu.si

\section{Notes}

[1] As part of Yugoslavia, from 1945 to 1991 Slovenia had a one-party communist system of government with socialist socioeconomic policies. Therefore the term communism is used in the article.

\section{Acknowledgement}

The authors acknowledge the support of the two anonymous reviewers for useful guidance in improving the quality and clarity of this article. We are also grateful for financial support from the Slovenian Research Agency for the project Cultural Landscapes Caught between Public Good, Private Interests, and Politics, ID J6-6854, and for research core funding no. P6-0101.

\section{References}

Anderies, J. M. \& Janssen, M. A. (2013) Sustaining the commons. Available at: http://sustainingthecommons.asu.edu/wp-content/uploads/2013/07/Sustaining-the-Commons-v101.pdf (accessed 1 Jun. 2015).

Bogataj, N. (2012) Model delovanja slovenskih agrarnih skupnosti. In: Rodela, R. (ed.) Soupravljanje naravnih virov: vaške skupnosti in sorodne oblike skupne lastnine in skupnega upravljanja, pp. 23-37. Wageningen, Netherlands, Wageningen University and Research Centre. Available at: http://edepot.wur.nl/205876 (accessed 10 Aug. 2017).

Caffentzis, G. (2010) The future of "the commons": Neoliberalism's "Plan B" or the original disaccumulation of capital? New Formations, 69, pp. 23-41. DOI: 10.3898/NEWF.69.01.2010

Cerar, G., Kliner, P. \& Papež, M. (2011) Prihodnost agrarnih skupnosti. Zelena dežela, 102, pp. 7-10.

Colloca, F., Cardinale, M., Maynou, F., Giannoulaki, M., Scarcella, G., Jenko, K., et al. (2013) Rebuilding Mediterranean fisheries: A new paradigm for ecological sustainability. Fish and Fisheries, 14(1), pp. 89-109. DOI: 10.1111/j.1467-2979.2011.00453.x

Czerny, T. A. (2014) Analiza skupnega upravljanja naravnih virov na primeru agrarne skupnosti Škrbina - Rubije - Šibelji. Master's thesis. Ljubljana, Univerza v Ljubljani, Biotehniška fakulteta.

Desmarais-Tremblay, M. (2014) On the definition of Public Goods. Assessing Richard A. Musgrave's contribution. Documents de travail du Centre d'Economie de la Sorbonne. Available at: https://halshs.archives-ouvertes.fr/halshs-00951577/document (accessed 29 Apr. 2018).

Drozg, V. (2005) Koncepti policentrične ureditve Slovenije. Dela, 24, pp. 147-158. DOI: 10.4312/dela.24.12.147-158

Drozg, V. (2007) Prispevek h gospodarski geografiji Slovenije. Revija za geografijo, 1/2(3), pp. 67-88.

Dupré, L. (1993) The common good and the open society. The Review of Politics, 55(4), pp. 687-712. DOI: 10.1017/S0034670500018052

Duraippah, A. K., Asah, S. T., Brondizio, E. S., Kosoy, N., O'Farrell, P. J., Prieur-Richard, A., et al. (2014) Managing the mismatches to provide ecosystem services for human well-being: A conceptual framework for understanding the new commons. Current Opinion in Environmental Sustainability, 7, pp. 94-100. DOI: 10.1016/j.cosust.2013.11.031

Fromentin, J. M. (2009) Lessons from the past: Investigating historical data from bluefin tuna fisheries. Fish and Fisheries, 10(2), pp. 197-216. DOI: 10.1111/j.1467-2979.2008.00311.x 
Godina, V. V. (2015) Zablode postsocializma. Ljubljana, Beletrina.

Grahek, S. (ed.) (1988) Komentar zakona o združenem delu. Ljubljana, Delo.

Hardin, G. (1968) The tragedy of the commons. Science, 162, pp. 12431248. DOI: 10.1126/science.162.3859.1243

Heinmiller, B. T. (2009) Path dependency and collective action in common pool governance. International Journal of the Commons, 3(1), pp. 131-147. DOI: 10.18352/ijc.79

Hooghe, L. \& Marks, G. (2003) Unraveling the central state, but how? Types of multi-level governance. American Political Science Review, 97(2), pp. 233-243.

Jaede, M. (2017) The concept of the common good. Available at: http:// www.politicalsettlements.org/publications-database/the-concept-ofthe-common-good/ (accessed 10 Feb. 2018).

Jepsen, M. R., Kuemmerle, T., Müller, D., Erb, K., Verburg, P. H., Haberl, $H_{\text {., }}$ et al. (2015) Transitions in European land-management regimes between 1800 and 2010. Land Use Policy, 49, pp. 53-64. DOI: 10.1016/j.landusepol.2015.07.003

Klemenčič, M. M. (1989) Družbenogospodarski prehod v Sloveniji. Dela, 6, pp. 230-243.

Klemenčič, M. M. (1997) Geografski prehod. Dela, 12, pp. 15-29.

Kluvánková, T. \& Gežík, V. (2016) Survival of commons? Institutions for robust forest social-ecological systems. Journal of Forest Economics, 24, pp. 175-185. DOI: 10.1016/j.jfe.2016.01.002

Kumer, P. (2017) Vpliv družbenogeografskih dejavnikov na gospodarjenje z majhnimi zasebnimi gozdnimi posestmi. Doctoral dissertation. Ljubljana, Filozofska fakulteta, Oddelek za geografijo.

Lee, S. (2018) Common good. In: Encyclopædia Britannica. Available at: http://corporate.britannica.com/ (accessed 10 Feb. 2018).

Lopes, L. L. G., Bento, J. M. R. S., Cristovão, A. F. A. C. \& Baptista, F. O. (2013) Institutionalization of common land property in Portugal: Tragic trends between "commons" and "anticommons". Land Use Policy, 35, pp. 85-94. DOI: 10.1016/j.landusepol.2013.05.007

Lorenčič, A. (2009) Pretvorba družbene lastnine v privatno - osrednji problem slovenske gospodarske tranzicije. Prispevki za novejšo zgodovino, 49(2), pp. 189-206.

Mansbridge J. (2013) Common good. In: LaFollette, H. (ed.) The International encyclopedia of ethics, vol. 2. Malden, MA, Wiley-Blackwell. DOI: 10.1002/9781444367072.wbiee608

Markuszewska, I. (2018) Conflicts between legal policy and rural area management in Poland. Acta geographica Slovenica, 58(1), pp. 59『67. DOI: 10.3986/AGS.1525

McKean, M. (2000) Common property: What is it? What is it good for? And what makes it work? In: Gibson, C. C., McKean M. A. \& Ostrom, E. (eds.) People and forest: Communities, institutions, and governance, pp. 27-55. Cambridge, MA, The MIT Press.

Melik, A. (1927) Kolonizacija Ljubljanskega barja. Ljubljana, Tiskovna zadruga.

Musgrave, R. A. (1969) Provision for social goods. Public Economics: An analysis of Public Production and Consumption and their Relations to the Private Sectors. London, Macmillan.

Musgrave, R. A. \& Musgrave, P. (1973) Public Finance in Theory and Prac tice. New York, McGraw Hill.

Obeng-Odoom, F. (2016) The meaning, prospects, and future of the commons: Revisiting the legacies of Elinor Ostrom and Henry George. The American Journal of Economics and Sociology, 75(2), pp. 372-414. DOI: 10.1111/ajes.12144
Omladič, L. (2016) Okoljska etika: kostanjeve vojne. Available at: http:// www.delo.si/novice/okolje/okoljska-etika-kostanjeve-vojne.html (accessed 16 Aug. 2017)

Ostrom, E. (1990) Governing the commons. The evolution of institutions for collective action. Cambridge, Cambridge University Press. DOI: 10.1017/CBO9780511807763

Ostrom, E. (2005) Understanding institutional diversity. Princeton, NJ, Princeton University Press.

Ostrom, E. (2010) Beyond markets and states: Polycentric governance of complex economic systems. American Economic Review, 100(3), pp. 641-672. DOI: 10.1257/aer.100.3.641

Ostrom, V. \& Ostrom, E. (1977) Public goods and public choices: The emergence of public economics and industry structures. In: Savas, E. S. (ed.) Alternatives for delivering public services: Toward improved performance. Boulder, CO, Westview Press.

Partlič, S. (1989) "Znanost" v agrarni politiki Jugoslavije. Teorija in praksa, 26, pp. 3-4.

Pavšič, J. (2008) Geologija barja in njegovega obrobja. In: Pavšič, J. (ed.) Ljubljansko barje - neživi svet, rastlinstvo, živalstvo, zgodovina in naravovarstvo, pp. 6-16, Ljubljana, Slovenska matica.

Petek, F. \& Urbanc, M. (2007) Common land in Slovenia. Geografski vestnik, 79(2), pp. 41-62.

Premrl, T. (2013) Analiza stanja agrarnih skupnosti v Sloveniji na podlagi podatkov upravnih enot. Research report. Ljubljana, Gozdarski inštitut Slovenije.

Premrl, T., Udovč, A., Bogataj, N. \& Krč, J. (2015) From restitution to revival: A case of commons re-establishment and restitution in Slovenia. Forest Policy and Economics, 59, pp. 19-26. DOI: 10.1016/j.forpol.2015.05.004

Pučnik, J. (1963) O dilemah našega kmetijstva. Perspektive, 4, pp. 33-34.

Ravnik, M. (1998) Soseska. In: Javornik, M. (ed.) Enciklopedija Slovenije, vol. 12, pp. 158-159. Ljubljana, Mladinska knjiga.

Razpotnik Visković, N. \& Seručnik, M. (2013) Respectability of the farming profession and part- time farmers in Slovene society after World War II. Geografski vestnik, 85(1), pp. 25-36.

Rodela, R. (2012) Uvod v skupno lastnino in skupno upravljanje naravnih virov. In: Rodela, R. (ed.) Soupravljanje naravnih virov: vaške skupnosti in sorodne oblike skupne lastnine in skupnega upravljanja, pp. 11-20. Wageningen, Netherlands, Wageningen University and Research Centre. Available at: http://edepot.wur.nl/205876 (accessed 16 Jan. 2017).

Samuelson, P. A. (1954) The pure theory of public expenditure. The Review of Economics and Statistics 36(4), pp. 387-389. DOI: $10.2307 / 1925895$

Schut, M., Cunha Soares, N., van de Ven, G. \& Slingerland, M. (2014) Multi-actor governance of sustainable biofuels in developing countries: The case of Mozambique. Energy Policy, 65, pp. 631-643. DOI: 10.1016/j.enpol.2013.09.007

Šetinc, F. (1979) Misel in delo Edvarda Kardelja. Ljubljana, Prešernova družba.

Sikor, T. (2004) The commons in transition: Agrarian and environmental change in central and eastern Europe. Environmental Management, 34(2), pp. 270-280. DOI: 10.1007/s00267-003-3007-5

Simoneti, M. (2016) Celovit sistem ukrepov za urejanje javnih zelenih površin v slovenskih naseljih. Doctoral dissertation. Ljubljana, Univerza v Ljubljani, Fakulteta za gradbeništvo in geodezijo.

Small, J. \& Witherick, M. (1986) A modern dictionary of geography. London, Hodder Arnold. 
Šmid Hribar, M. (2016) Varovanje in trajnostni razvoj kulturne pokrajine na primeru Ljubljanskega barja (= Georitem 27). Ljubljana, Založba ZRC.

Šmid Hribar, M., Bole, D. \& Urbanc, M. (2015) Public and common goods in the cultural landscape. Geografski vestnik, 87(2), pp. 43-57. DOI: 10.3986/GV87203

Smith, A. \& Timár, J. (2010) Uneven transformations: Space, economy and society 20 years after the collapse of state socialism. European Urban and Regional Studies, 17(2), 115-125. DOI: $10.1177 / 0969776409358245$

Somerville, P. \& Haines, N. (2008) Prospects for local co-governance. Local Government Studies, 34(1), pp. 61-79.

DOI: $10.1080 / 03003930701770488$

Tomšič, M. \& Vehovar, U. (2012) Quality of governance in "old" and "new" EU member states in a comparative perspective. Slovak Sociological Review, 44(3), pp. 367-384.

Toplak, C. (2014) "Za nov družbeni red": genealogija samoupravljanja. Ars \& humanitas, 8(1), pp. 118-135. DOI: 10.4312/ah.8.1.118-135

Urbanc, M. (2002) Kulturne pokrajine v Sloveniji (= Geografija Slovenije 5). Ljubljana, Založba ZRC.

Ustavni zakon o dopolnitvi III. poglavja Ustave republike Slovenije (UZ70a). Uradni list Republike Slovenije, no. 75/2016. Ljubljana.

Vilfan, S. (1996) Zgodovinska pravotvornost in Slovenci. Ljubljana, Cankarjeva založba.

Vugrin, M. (2005) Definiranje pojma javno dobro. Geodetski vestnik, 49(3), pp. 416-423.

Zakon o agrarni reformi in kolonizaciji. Uradni list LRS, nos. 10/1948, 17/1958, 17/1959, 18/1961, and 22/1965. Ljubljana.

Zakon o agrarnih skupnostih. Uradni list LRS, no. 52/1947. Ljubljana.

Zakon o denacionalizaciji. Uradni list RS, nos. 27/1991-I, 56/1992 - odl. US, 13/1993 - odl. US, 31/1993, 24/1995 - odl. US, 20/1997 - odl. US, 23/1997 - odl. US, 65/1998, 76/1998 - odl. US, 66/2000, 66/2000 ORZDen27, 11/2001 - odl. US, 54/2004 - ZDoh-1, and 18/2005 - odl. US. Ljubljana.

Zakon o kmetijskem zemljiškem skladu splošnega ljudskega premoženja in o dodeljevanju zemlje kmetijskim organizacijam. Uradni list FLRJ, no. 22/1953. Ljubljana.

Zakon o razpolaganju s premoženjem bivših agrarnih skupnosti. Uradni list SRS, no. 7/1965. Ljubljana.

Zakon o združenem delu (ZZD). Uradni list SFRJ, no. 53/1976. Ljubljana.

Zakon o upravljanju državnih in gospodarskih podjetij in višjih gospodarskih združenj po delovnih kolektivih. Uradni list FLRJ, no. 43/1950. Ljubljana.

Zlatkova, I. M. (2015) Gardening the city: Neighbourliness and appropriation of common spaces in Bulgaria. Colloquia Humanistica, 4, pp. 41-60. DOI: 10.11649/ch.2015.012 